Divine Love 
This page intentionally left blank 


\title{
Divine Love
}

Islamic Literature and the Path to God

\section{William C. Chittick}

Foreword by Seyyed Hossein Nasr

\author{
Yale \\ UNIVERSITY \\ PRESS
}

New Haven G London 
Published with assistance from the foundation established in memory of Philip Hamilton McMillan of the Class of 1894 , Yale College.

Copyright (C) 2013 by William C. Chittick.

All rights reserved.

This book may not be reproduced, in whole or in part, including illustrations, in any form (beyond that copying permitted by Sections 107 and 108 of the

U.S. Copyright Law and except by reviewers for the public press), without written permission from the publishers.

Yale University Press books may be purchased in quantity for educational, business, or promotional use. For information, please e-mail sales.press@yale.edu (U.S. office) or sales@yaleup.co.uk (U.K. office).

Set in Postscript Electra type by Westchester Book Group.

Printed in the United States of America.

Library of Congress Cataloging-in-Publication Data

Chittick, William C.

Divine love : Islamic literature and the path to god / William C. Chittick.

pages $\mathrm{cm}$

Includes bibliographical references and index.

ISBN 978-0-300-18595-9 (alk. paper)

1. Sufism. 2. Sufi literature-History and criticism. I. Title.

BP189.C 5272013

$297.2^{\prime} 11-\mathrm{dc} 23$

2012044733

A catalogue record for this book is available from the British Library.

This paper meets the requirements of ANSI/NISO Z39.48-1992

(Permanence of Paper). 